Two particular soil types are specified as being liable under certain conditions to give rise to tirak : these are light sandy loams deficient in nitrogen, and soils which contain free sodium salts or sodium clay in the subsoil. Different types of physiological disorder are induced under the two sets of conditions, but the name tirak is still retained to cover both. The more evident symptoms which develop on the first soil type have already been indicated; but in addition it has been found that in the leaves of affected plants there is an abnormal accumulation of starch in the cells of the mesophyll. This starch is not removed during the night, as in normal leaves, but continues to accumulate until in extreme cases the chloroplasts become ruptured. An abnormal accumulation of a tannin-like substance is also present in the cells, its presence being antecedent to the development of the external symptoms of tirak. The relation of these abnormal developments to nitrogen deficiency has been established by appropriate experimentation. The observation that, on light sandy loams, tirak cannot be attributed to nitrogen deficiency alone led to investigations of the water economy of the plant. Water deficiency during the reproductive phase was also found to be a factor in the situation. Thus where water deficiency is important, as in soils with subsoil salinity, affected plants show a pronounced drooping of the leaves; these leaves also become dark-coloured and dull, they lose their fresh green shining appearance and are prematurely shed. In this type of tirak the yellowing seen in nitrogendeficient plants is not present; there is likewise no evidence of the accumulation of starch or tannin, but cortain protoplasmic abnormalities are evident. Both types of tirak-affected plants are characterized by a low potassium content in leaves and carpels, depressed synthesis of proteins, and decreased oil formation in seeds.

A careful consideration of all the relevant biochemical data has led to the conclusion that the low potassium content is the starting-point of the internal disorders in tirak plants. The disorders associated with this deficiency develop in different ways in plants growing on the two soil types : in the light sandy loams the uptake of potassium is low because of the shortage of nitrogen; on saline soils physiological drought interferes with the normal uptake of minerals. Thus Prof. Dastur concludes (p. 71): "The common symptom, viz., immaturity of seed, therefore, developed in plants on both soil types though the symptoms exhibited by the leaves of tirak-affected plants on the two soil types were found to differ". Such a finding gives some idea of the difficulties inherent in the investigation of a crop failure which is due to physiological disorders.

Broadly speaking, the field aspect of the problem has been diagnosed along the following lines. When Punjab-American cottons are sown early in May, the combination of light soil, long days and regular water supply makes for strong vegetative growth. Flowering begins about the last week in August. It is a curious and important fact that any change in the date of sowing is not accompanied by a similar shift in the onset of flowering; that is, all sowings tend to come into bearing within a rather narrow period. Moreover, flowering tends to occur in a flush and thus imposes a heavy demand on the supplies of nitrogen and other minerals. This is particularly so in the case of the strongly vegetative plants which result from the early May sowings. In point of fact, a large number of flowers do not come into fruition as fully developed bolls. This tends to be accentuated in soils which are deficient in nitrogen or which suffer from physiological drought, with the concomitant develop. ment of the two types of failure described as tirak. These and many other interesting aspects of the problem are fully described and discussed.

A substantial part of the report deals with the remedial measures to be adapted to different soil types. To quote from the report (p. 137): "The application of nitrogen to light sandy soils prevented the development of tirak symptoms caused by nitrogen starvation and the application of extra water at the fruiting stage prevented the development of physiological drought on soils with saline subsoils. Both these remedies proved specific for the two soil types and naturally they must be applied at the right place.

"The importance of the June-sowings as a pre. ventive measure against tirak was its gen'eral applic. ability. It was found efficacious on all soil types as it put the crop in equilibrium with its surroundings. . . The plants were able to carry on their normal functions with less nitrogen and less water [than the May-sowings] and the deficiency of these substances did not develop. The plants were also better able to stand the adverse weather conditions at the fruiting stage and thus general intensification and spread of tirak were greatly lessened. The internal economy of the plant greatly improved and the plant produced less of sticks and more of fruits. . . . This simple measure of deferring sowings by about three to four weeks has been found to result in great profits to cotton growers and many of them have already. benefited."'

Prof. Dastur and his collaborators, and the Indian Central Cotton Committee which sponsored and financed the work, are to be congratulated on the successful outcome of this long and intricate investi: gation.

\section{TRANSMISSION OF FINGER-PRINTS} BY RADHO

THE transmission pictures and of written or printed materid frover line and radio telegraphic circuits is an formevement of long standing; but in recent years. Chormous advances have been made in the tec pique of radio transmission and reception in the field, resulting in very marked improvement in no quality and detail of the reproduced pictures, excellent examples of which are frequently to be seen in the daily. Press. The successful transmission to a distance of reproductions of human finger-prints. obviously demands an unusually high quality in this. technique, and a study of the problems involved in this. application has been the object of tests conducted during the past year between Great Britain and Australia.

These tests are described in an interesting pamphlet entitled "Radio Transmission of Finger Prints", by. Superintendent F. R. Cherrill, officer-in-charge of the. Finger Print Branch, New Scotland Yard*. A foreword to this document refers to an article entitled. "The Description and Use of the Pores in the Skin of the Hands and Feet", published in the Philosophical Transactions of the Royal Society in 1684 by Dr. Nehemiah Grew, who was at one time secretary.

* Radio Transmission of Finger Prints. By Supt. F. R. Cherrill. Pp. 12. (Commissioner of Police of the Metropolis, New Scotland Yard, London, S.W.1, 1946.) 
of the Society. A drawing of a hand emphasizing the features of finger- and palm-print patterns is reproduced from this article. The memorandum is, however, essentially concerned with the results of successful tests in the long-distance identification of criminals conducted during the past year by New Scotland Yard in co-operation with the Commissioner of Police, Victoria, Australia, and Messrs. Cable and Wireless, Ltd.

The report is illustrated by a specimen transmission card which contains, in addition to two photographs of the wanted person, an enlarged print of one finger with coded description of the other nine digits, and a complete description of the individual, and the information required in connexion with him. All this matter is contained on a card approximately 10 in. $\times 9$ in. in size; and this formed the picture which in one test was transmitted from London to Melbourne in seven minutes so successfully that a cable setting forth the person's record was received from Melbourne the next morning. These tests thus culminated in the successful identification in Australia of a person who was actually in custody in Great Britain and whose trial was imminent. Similar facilities for radio picture transmission are now available between London and many towns in various parts of the world, both within and outside the British Empire.

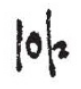

\section{BIRDS OF PALESTINE}

$\mathrm{W}$ HULE cerying in Palestine, Captain Eric Hardy became 10 secretary of the Jerusalem Naturalists Club wh ch had been founded for the troops by Middle Command to stimulate interest in and co-ordinat the numerous inquiries in natural history tha ore already being pursued by a number of inf hdual soldiers. One of the most notable activities of the Club was the listing of the birds of Palestine. The duty was undertaken because of the lack of a modern and authoritative account of Palestinian birds, and, besides their records of 364 species and 68 sub-species, work was also carried out on problems of migration. These, together with records of the most-used bird haunts, have been put together by Captain Hardy in a privately printed list which, it is hoped, will be the forerunner of an authoritative and comprehensive handbook of "Palestinian ornithology*.

The region is of particular interest becaúse the Palæarctic region of the north and the Ethiopian region of the south meet across the centre of the country. The little owl, for example, shows interesting northern, southern and intermediate races, and several African birds like the sunbird (Cinuyris), the darter (Anhinga), the sooty falcon and the lappetfaced vulture (Otogyps) penetrate the country from the Syro-African Rift Valley, and oriental birds like the fishing owl (Ketupa) and the black-headed bunting (Emberiza melanocephala) also occur. The main migration routes between Europe and Africa pass through the country.

The only native bird to migrate to Palestine is the gannet (Sula bassana), although several 'British' species from eastern Europe, like the European swallow, the rook, redshank, teal and cuckoo, are seen. There are also several closely allied races of

* A Handbook of the Birds of Pllestine. By Captzin Eric Hardy. Pn. iii + 50. (Education Othicer-in-chief. G.H.Q., Middle East Forces, 1946.) the birds known in Britain, like the chaffinch, great tit, kingfisher, robin, song thrush and blackbird. The blackbird, skylark and song thrush do not sing in Palestine in their winter sojourn, and the robin sings only occasionally at daybreak. The cuckoo rarely calls on its migration; nightjars do not sing. Absence of bird song, particularly thrush song, is noticeable to the British visitor, but the song-birds common to Britain and Palestine are the greenfinch, great tit, chaffinch, goldfinch, corn-bunting and, occasionally, the chiff-chaff. The familiar calls of the robin and redshank are commonly heard in winter, but the robin, as well as the blackbird and song thrush, are much shier and less easy to approach than in Britain. Birds peculiar to Palestine include the Palestine babbler, the Palestine blackstart, the Palestine graceful warbler, Tristram's grackle and the Palestine sunbird. The grackle and the sunbird are extending their way northwards from the Dead Sea depression. The bulbul is supposed to have increased its numbers considerably this century, but several birds have decreased. The white stork, the lammergeir, the imperial eagle and the white-faced duck no longer nest in the country, while the great bustard, the Syrian ostrich and the Egyptian goose are apparently extinct in Palestine. Unlike Cairo, Jerusalem and the cities of Palestine are not the habitat of flocks of kites, but also unlike Cairo, Jerusalem, Haifa and Tel Aviv have a large summer nesting population of swifts.

\section{CARNEGIE INSTITUTION OF WASHINGTON}

$\mathrm{O}^{\mathrm{N}}$ $\mathrm{NE}$ of the lost interesting passages in the report of the sident of the Carnegie Institution of Washingty, Ir. Vannevar Bush, which is included, togempr dith the reports of the executive committee, the atcortors, and on departmental activities, in the Yeakbok No. 44 for 1944-45, covering the year July 1, 1944-June 30, 1945, is that in which he discusses the future of scientific research, and particularly the bearing on it of the Selective Service, the further extension of which as regards science and engineering students has since been severely criticized by H. A. Meyerhoff (Science, April 19). Dr. Bush points out first that while the United States is at last awake to the value of scientific research, it is not by any means certain that every area where the scientific method can add to man's understanding of himself and his environment will be adequately explored, and that the danger of lack of balance between applied research, research in the physical sciences, medical science and in other fields may be exaggerated by the serious deficit in scientific man-power due to the policies pursued during the War. The two governing principles, that every citizen should be ready to sacrifice equally in the common cause and that every man should be used in the place where his talents can contribute most fully to the common effort, were not in balance. As a result, by taking too many trained young scientific workers and engineers out of the laboratories and industry, part of the war effort was nearly wrecked, while at the same time the future was sucrificed to immediate needs and a lack of scientific man-power created from which the country will not recover for many years. 